\title{
Productive performance and carcass characteristics of New Zealand white and California rabbits and their crosses
}

\author{
Macías-Fonseca, Mario Enrique ${ }^{1}$; Herrera-Haro, José Guadalupe ${ }^{1^{*}}$; Pro-Martínez, Arturo ${ }^{1}$; \\ Ortega-Cerrilla Ma. Esther ${ }^{1}$; Ruíz-Sesma, Benigno ${ }^{2}$ \\ ${ }^{1}$ Colegio de Posgraduados, Campus Montecillo. Montecillo, Texcoco, Estado de México. C.P. 56230. \\ ${ }^{2}$ Universidad Autónoma de Chiapas. Facultad de Medicina Veterinaria y Zootecnia. Tuxtla Gutiérrez, \\ Chiapas, México. C.P. 34000. \\ *Corresponding author: haro@colpos.mx
}

\begin{abstract}
Objective: To evaluate the growth, performance, and carcass characteristics as well as the individual and maternal heterosis effects of New Zealand White (NZ), California (CA) rabbits and their crosses.

Design/methodology/approach: 450 offspring rabbits, from 48 females (does) mated to six stud rabbits, were evaluated, recording the weight (BLW) and litter size at birth (LSB) and weaning (LSW), as well as the weight (AWW), gain (AWG), consumption (AWC), and feed conversion (CONV) for 8 weeks post-weaning. The carcass live weight at slaughter, warm carcass weight with head, carcass yield and parts of the carcass were evaluated.

Results: The assessment showed differences $(\mathrm{P}<0.05)$ in LSB and LSW with values of 10.47 and 9.78 kits respectively, when NZ was used as the paternal breed, results suggest individual heterosis of 5.91\% for litter size and $12.44 \%$ for the weaning weight. Regarding the productive performance and carcass characteristics, the California breed showed superiority as a paternal breed, with average values of $36.11 \mathrm{~g}$ in AWG and 2.90 in CONV. The average individual weight at the end of the fattening, at 70 days of age, was $2.09 \mathrm{~kg}$ and the carcass weight was $1.16 \mathrm{~kg}$. Post-weaning heterosis for the evaluated characteristics during fattening was positive and moderate.

Limitations on study/implications: It is necessary to carry out genetic improvement studies, with different crossing systems and to evaluate results based on productive and reproductive performance.

Findings/conclusions: When using NZ as a paternal breed, the reproductive characteristics of the offspring were superior compared to the ones obtained from CA. In contrast, the reproductive variables were superior in CA breed in comparison to NZ.
\end{abstract}

Keywords: rabbit breeding, litter size, weight gain, carcass yield.

\begin{abstract}
Citation: Macías-Fonseca, Mario Enrique, Herrera-Haro, José G., ProMartínez, Arturo, Ortega- Cerrilla Ma. Esther, \& Ruíz-Sesma, Benigno. (2021). Productive performance and carcass characteristics of New Zealand white and California rabbits and their crosses. Agro Productividad, 14(\#). https://doi. org/10.32854/agrop.v14i6.1916
\end{abstract}

Editor in Chief: Dr. Jorge Cadena Iñiguez

Estimated publication date: July 2021

This work is licensed under a Creative Commons Attribution-NonCommercial 4.0 International license

\section{INTRODUCTION}

In Mexico, rabbit breeding in family-based farms is carried out with New Zealand White (NZ), California (CA) and Chinchilla breeds, as well as a wide range of crosses, constituting a source of income and good quality protein for rural families, thus, rabbit breeding is considered an activity for ensuring food security (SAGARPA, 2010). The estimation of productive, reproductive and profitability indexes in rabbit farms can aid in the calculation of their potential performance (Lukefahr and Cheeke, 1991), besides offering useful information about pure breeds and commercial crossbreeds. NZ White and CA breeds have great potential as pure breeds, maximizing the percentage of heterosis in their crosses and used in the creation of genetic lines (Blumetto, 2007). They have good muscle conformation, high prolificity and growth rate (Ortiz and Rubio, 2001). Heterosis between crosses of these breeds is greater in reproductive characteristics than in growth characteristics, manifesting itself in a greater number of kits at weaning. This superiority is greater when the breeds differ widely in gene 
frequencies with a minimum of genotype-environment interactions (Falconer and Mackay, 1996), requiring further research in local rabbit populations. The objective of this research was to evaluate the productive performance, carcass characteristics and individual heterosis of some productive traits in NZ, CA rabbits and their crosses.

\section{MATERIALS AND METHODS}

\section{Ethical Statement}

Sampling, handling, and slaughter of the animals were carried out following the Experimental Regulation Protocol and following the Mexican Official Standard (Norma Oficial Mexicana, NOM-033-ZOO-1995), which refers to the humane slaughter of domestic and wild animals; the above, approved by the Colegio de Postgraduados, Mexico.

\section{Study site}

From February to December 2019, research was conducted at the rabbit production module of the Colegio de Postgraduados, Campus Montecillo, located at 19²7'34.8” LN and $98^{\circ} 54^{\prime} 15.8^{\prime \prime}$ LO, in Texcoco, Estado de Mexico.

\section{Feeding}

Controlled commercial feed was provided to obtain the average weekly intake (AWI) in two variants; for does, with a 15.55\% protein, $16.26 \%$ fiber and $2.91 \%$ fat content; for the fattening progeny with $16.5 \%$ protein, $15 \%$ fiber and $3 \%$ fat.

\section{Experimental procedure}

Data were obtained from a 48 first-calving females sample from a rabbit population of 160 females. Preweaning characteristics of NZ and CA females and their crosses were evaluated. During the first stage, NZ and CA breeders were mated with six males, three $\mathrm{NZ}$ and three CA, and classified into four genetic groups (treatments): T1: NZ $\times$ NZ, T2: CA $\times$ CA, T3: NZ (sire) $\times$ CA (dam) and T4: CA (sire) $\times$ NZ (dam). In the second stage, six weaned kits were selected from each female and transferred to fattening cages with an identification ear tattoo and weighed individually for five weeks. At the end of the fattening stage, 350 randomly selected animals were slaughtered to evaluate their carcass characteristics.

\section{Evaluated characteristics}

Preweaning stage. Maternal ability was recorded in the parents: nest preparation, live and stillborn kits, their viability from birth to weaning, litter size and weight at birth and weaning (35 days) and mortality.

Fattening stage. Weight (AWW), weight gain (AWG), feed intake (AWC) and feed conversion (CONV) were evaluated weekly, using 112 replicates per treatment.

Carcass evaluation. After slaughter, the carcass was fractionated following the protocol by Blasco et al. (1992). Live weight at slaughter, carcass weight with head, 
carcass yield and carcass parts (leg, loin, arms, kidney, liver, green and red viscera) were measured and classified by sex.

Individual heterosis $(\mathrm{H})$ was estimated by the difference between the average of the reciprocal crosses minus the average of the parents divided by the average of the parents (Falconer and Mackay, 1996).

\section{Statistical analysis}

In the preweaning stage data, an analysis of variance was performed using the PROC GLM of SAS statistical software (SAS, 2012), with a one-way classification model. To evaluate the parents for preweaning progeny performance, two groups of treatments were formed, the first with progeny from NZ parents and the second with progeny from CA parents. For the analysis of the fattening stage, the PROC MIXED of the SAS statistical software (SAS, 2012) was used, which included the fixed effects of treatment, time and their interaction. To ascertain mean differences, a Tukey's test $(\alpha<0.05)$ was used.

$$
\text { Model: } Y_{i j k l}=\mu+R_{i}+\delta_{j i}+S_{k}+(R S)_{i k}+\varepsilon_{i j k l}
$$

Where: $Y_{i j k l}=$ Growth trait in the $i j k$-th evaluated doe; $\mu=$ Overall mean; $R_{i}=$ Fixed effect of $i$-th genetic group; $\delta_{j i}=$ Error of $j$-th animal within $i$-th genetic group; $S_{k}=k$-th week of evaluation; $(R S)_{i k}=$ Effect of genetic group $\times$ week interaction; $\boldsymbol{\varepsilon}_{i j k l}=$ Random error.

The carcass evaluation considered live weight at slaughter as a covariate, according to the model:

$$
Y_{i j k l}=\mu+R_{i}+\beta\left(X_{i j}-\bar{X}\right)+\varepsilon_{i j k l}
$$

Where: $Y_{i j k l}=$ Carcass characteristic in $i j$-th evaluated rabbit; $\mu=$ Overall mean; $R_{i}=$ Fixed effect of the $i$-th genetic group; $\beta\left(X_{i j}-\bar{X}\right)=$ Effect of the covariate live weight of rabbits at slaughter $\varepsilon_{i j k l}=$ Random error.

\section{RESULTS AND DISCUSSION}

\section{Litter size and litter survival in the pre-weaning period}

Table 1 shows differences $(\mathrm{P}<0.05)$ in litter size at birth (LSB) and weaning (LSW), values that concur with Piles et al. (2005) who indicated superiority in LSB and survival of the NZ breed and the NZ×CA crosses. Statistical analyses showed no differences $(\mathrm{P}>0.05)$ between breeds in birth weight (LWB). The mean number of kits per female at parturition was 10.40 and at weaning 8.94 for NZ and CA breeds, which is higher than that described by Vásquez et al. (2007), in the NZ breed, in the Sabana de Bogotá, Colombia. 
Table 1. Analysis of pre-weaning variables of the New Zealand and California breeds and their reciprocal crosses.

\begin{tabular}{l|c|c|c|c}
\multirow{2}{*}{\multicolumn{1}{c|}{ Variable }} & \multicolumn{4}{c}{ Treatments } \\
\cline { 2 - 5 } & NZW Parents & CA Parents & SEM & P>F \\
\hline Litter size at birth & $10.47 \mathrm{a}$ & $10.32 \mathrm{~b}$ & \pm 0.08 & $0.034^{*}$ \\
\hline Number live-born kits & $9.78 \mathrm{a}$ & $9.67 \mathrm{a}$ & \pm 1.02 & 0.057 \\
\hline Mortality at birth & $0.53 \mathrm{a}$ & $0.64 \mathrm{a}$ & \pm 0.56 & 0.054 \\
\hline Litter weight at birth (g) & $574.87 \mathrm{a}$ & $586.46 \mathrm{a}$ & \pm 17.13 & 0.090 \\
\hline Litter size at weaning & $9.03 \mathrm{a}$ & $8.85 \mathrm{~b}$ & \pm 0.19 & $0.045^{*}$ \\
\hline Average weaning weight (g) & $972.02 \mathrm{a}$ & $909.99 \mathrm{~b}$ & \pm 31.81 & $0.029^{*}$ \\
\hline Total mortality (birth-weaning) & $1.37 \mathrm{a}$ & $1.25 \mathrm{a}$ & \pm 0.36 & 0.331 \\
\hline Total percentage of mortality & $12.43 \mathrm{a}$ & $11.71 \mathrm{a}$ & \pm 4.42 & 0.370 \\
\hline
\end{tabular}

a,b,Means within rows with different literals are different $\left(\mathrm{P}<0.05^{*}\right)$, SEM: standard error mean. NZ: New Zealand parents, CA: California parents

\section{Litter weight at birth and weaning}

The average litter weight at birth (LWB) was $580.66 \mathrm{~g}$, with an individual weight of $56.1 \mathrm{~g}$, and an average individual weaning weight of $941 \mathrm{~g}$ (Table 1). The results at birth are similar to those of Diaz (2006), who reported birth weights of 50 to $75 \mathrm{~g}$ in the NZ breed and crossbred progeny. The present results are higher than those reported by Ponce de León et al. (2002) who reported birth weights of $562.22 \mathrm{~g}$ for NZ parents. Contrastingly, Gallego (2016) reported that the offspring of NZ parents reached a higher weight at weaning than the progeny of CA parents, attributable to the additive effects of NZW males and the individual heterosis possessed in this trait; contrary to what was obtained in the LWB variable. Offspring from CA parents at weaning obtained a lower average weight (909.99 g), similar to the values reported by Lukefahr et al. (2000). New Zealand White females were superior to CA females in their reproductive traits. The contribution of maternal effects was higher in the NZ breed (Table 1).

The heterosis obtained for live births and survival during the preweaning period, within the four genetic groups, was positively superior by 5.91 and 4.99\%, respectively, from the crossbred progeny (Table 2), coinciding with Brun and Baselga (2005), that report positive heterosis effects of the crossbred progeny and values with a $6 \%$ superiority. The heterosis found in birth weight was 5.29\%, a value lower than that reported by Youssef (2004) who indicates a 6\% superiority in the birth weight of the NZ breed and reciprocal crosses with CA.

Table 2. Direct effects of heterosis on litter size at birth, survival rate, birth and weaning weight and percentage of heterosis in rabbit breed.

\begin{tabular}{l|c|c|c|c}
\multicolumn{1}{c|}{ Maternal breed } & Litter size at birth & Survival rate (\%) & Birth weight (g) & $\begin{array}{c}\text { Weaning } \\
\text { weight (g) }\end{array}$ \\
\hline California & $10.36 \mathrm{~b}$ & $92.32 \mathrm{a}$ & $574.46 \mathrm{a}$ & $962.98 \mathrm{~b}$ \\
\hline New Zealand White & $10.44 \mathrm{a}$ & $94.73 \mathrm{a}$ & $589.07 \mathrm{a}$ & $919.42 \mathrm{a}$ \\
\hline Heterosis (\%) & 5.91 & 4.99 & 5.29 & 12.44 \\
\hline
\end{tabular}

a,b, Means within columns with different literals are different $\left(\mathrm{P}<0.05^{\star}\right)$. 
The progeny of the NZ $\times$ CA cross showed a superior weaning weight (12.44\%) in relation to its parental breeds which, complemented with litter survival at birth, demonstrates it was the cross with the best performance of the evaluated genetic groups. This heterosis is considered of medium and moderate impact on the productivity in breeding systems and concurs with Gallego (2016) and Youssef (2004) who report similar results with a $13 \%$ value.

\section{Fattening phase}

Table 3 shows the means of the evaluated breeds in the fattening phase. The CA progeny had a higher increase $(\mathrm{P}<0.05)$ in $\mathrm{AWG}$, with a mean of $35.99 \mathrm{~g}$ and a ratio of $2.90 \mathrm{~kg}$ feed per $\mathrm{kg}$ live weight, compared to offspring from NZ parents. However, there were no differences between breeds for weight and weekly feed intake variables.

Table 3. Analysis of fattening stage variables (g) in the New Zealand (NZ), California (CA) rabbit breeds and their crossbreeds.

\begin{tabular}{c|l|c|c|c|c}
\hline \multicolumn{2}{c|}{ Variable } & AWG & AWW & AWC & CONV \\
\hline \multirow{4}{*}{ Treatment (T) } & $(\mathrm{NZ})$ & $33.62 \mathrm{~b}$ & $1914.96 \mathrm{a}$ & $104.58 \mathrm{a}$ & $3.22 \mathrm{~b}$ \\
\cline { 2 - 6 } & $(\mathrm{CA})$ & $35.99 \mathrm{a}$ & $1970.57 \mathrm{a}$ & $101.97 \mathrm{a}$ & $2.90 \mathrm{a}$ \\
\cline { 2 - 6 } & $\mathrm{NZ} \times \mathrm{CA}$ & $34.54 \mathrm{ab}$ & $1946.49 \mathrm{a}$ & $104.97 \mathrm{a}$ & $3.03 \mathrm{ab}$ \\
\cline { 2 - 6 } & $\mathrm{CA} \times \mathrm{NZ}$ & $36.11 \mathrm{a}$ & $1979.39 \mathrm{a}$ & $103.22 \mathrm{a}$ & $3.00 \mathrm{ab}$ \\
\cline { 2 - 6 } & SEM & \pm 0.67 & \pm 54.13 & \pm 3.09 & \pm 0.12 \\
\hline \multirow{5}{*}{ Week $(\mathrm{W})$} & ONE & $33.98 \mathrm{a}$ & $941.20 \mathrm{a}$ & $60.90 \mathrm{a}$ & $1.81 \mathrm{a}$ \\
\cline { 2 - 6 } & TWO & $35.97 \mathrm{a}$ & $1184.06 \mathrm{a}$ & $81.46 \mathrm{a}$ & $2.28 \mathrm{a}$ \\
\cline { 2 - 6 } & THREE & $37.11 \mathrm{a}$ & $1466.61 \mathrm{a}$ & $110.45 \mathrm{a}$ & $3.06 \mathrm{a}$ \\
\cline { 2 - 6 } & FOUR & $33.52 \mathrm{a}$ & $1724.06 \mathrm{a}$ & $121.31 \mathrm{a}$ & $3.81 \mathrm{a}$ \\
\cline { 2 - 6 } & FIVE & $34.76 \mathrm{a}$ & $1968.92 \mathrm{a}$ & $143.30 \mathrm{a}$ & $4.22 \mathrm{a}$ \\
\cline { 2 - 6 } & SEM & \pm 0.78 & \pm 31.96 & \pm 2.31 & \pm 0.11 \\
\hline \multirow{2}{*}{ Interactión $(\mathrm{p}>\mathrm{F}) \mathrm{T} \times \mathrm{W}$} & & $0.0049 * *$ & 0.8228 & 0.6675 & $0.0359^{*}$ \\
\hline
\end{tabular}

a,b, Means within columns with different literals are different $\left(\mathrm{P}<0.05^{*}\right.$ y $\left.\mathrm{P}<0.01^{* *}\right)$. AWG: average weekly gain, AWW: average weekly weight, AWC: average weekly consumption and CONV: average feed conversion.

These results coincide with those by Piles et al. (2005) where the superiority of the CA compared to NZ regarding weight gain and feed conversion was reported and no differences were found in feed intake and final weight.

The obtained values in this study for the evaluated crosses are higher than those reported by Palmieri (2006) who crossed CA with NZ breeds and reported post-weaning weight gains of $30 \mathrm{~g}$ per day. Blumetto (2007) recorded a daily weight gain of 35.54 to $36.51 \mathrm{~g}$, similar to those reported in the present study. The heterosis in weight gain and final weight in the four genetic groups was 33.33 and 24.75\%, respectively (Table 4). These are of high heritability and higher than those found by Zaghloul et al. (2019) and Khalil and Al-Homidan (2014) who report heterosis of 18 to 34\% in weight gain and 19 to $20 \%$ at final weight. 
Table 4. Direct effects of individual heterosis on progeny characteristics in the fattening phase of rabbit breeds.

\begin{tabular}{l|c|c|c|c}
\multicolumn{1}{c|}{ Paternal breed } & Weight gain & Final weight & $\begin{array}{c}\text { Feed } \\
\text { consumption }\end{array}$ & $\begin{array}{c}\text { Feed } \\
\text { conversion }\end{array}$ \\
\hline California & $36.05 \mathrm{a}$ & $1974.98 \mathrm{a}$ & $102.59 \mathrm{a}$ & $2.95 \mathrm{a}$ \\
\hline New Zealand White & $34.08 \mathrm{~b}$ & $1930.72 \mathrm{a}$ & $104.77 \mathrm{~b}$ & $3.12 \mathrm{~b}$ \\
\hline \% Heterosis & 33.33 & 24.75 & 22.58 & 23.44 \\
\hline
\end{tabular}

a,b. Means within columns with different literals are different $\left(\mathrm{P}<0.05^{\star}\right)$.

Regard feed consumption and CONV, the heterosis found was $22.58 \%$ and $23.44 \%$, respectively, which are of moderate tendency. The results described here were superior to those found by Youssef (2004) and Piles et al. (2004) who reported a 20\% heterosis in the feed intake and 22\% in CONV.

Table 5 shows the superiority of the progeny from CA breed parents in live weight at slaughter (2094.87 g) and carcass weight (1164.21 g); no differences were found in yield and carcass parts $(\mathrm{P}>0.05)$.

\section{Carcass characteristics}

Gender did not influence the evaluated characteristics. Trocino et al. (2003) indicate that sex influences the weight and parts of the carcass at slaughter when the live weight is greater than $2.5 \mathrm{~kg}$. Barrón et al. (2004) indicate that rabbits are slaughtered before puberty with an average weight of $2.1 \mathrm{~kg}$. The results obtained are similar to those reported by Boicoc (2002), who registered a slaughter weight of 1998 $\mathrm{g}$ for NZ and $2040 \mathrm{~g}$ for CA breeds beds and shows the importance of heterosis in the crossbreeding of rabbits, whose reported weights were $2160 \mathrm{~g}$ at the end of fattening in a CA $\times$ NZ cross.

Table 5. Analysis of the carcass characteristics in New Zealand (NZ) and California (CA) rabbit breeds and their crosses.

\begin{tabular}{|c|c|c|c|c|c|c|c|c|}
\hline Treatment & $\begin{array}{c}\text { Live weight } \\
\text { (g) }\end{array}$ & $\begin{array}{c}\text { Carcass } \\
\text { weight }(\mathbf{g})\end{array}$ & $\begin{array}{c}\text { Dressing } \\
\text { percentage } \\
(\%)\end{array}$ & Loin(g) & Legs (g) & Arms (g) & Kidney (g) & Liver (g) \\
\hline NZ & $1920.74 b$ & $1055.97 \mathrm{~b}$ & $55.23 \mathrm{a}$ & $172.18 \mathrm{a}$ & $273.48 \mathrm{a}$ & $139.74 a$ & $21.81 \mathrm{a}$ & $70.44 a$ \\
\hline CA & $2078.54 \mathrm{a}$ & $1156.18 \mathrm{a}$ & $55.51 \mathrm{a}$ & $176.81 \mathrm{a}$ & $272.50 \mathrm{a}$ & $145.49 a$ & $21.90 \mathrm{a}$ & $70.62 \mathrm{a}$ \\
\hline $\mathrm{NZ} \times \mathrm{CA}$ & $1964.75 b$ & $1083.65 b$ & $55.29 a$ & $175.75 \mathrm{a}$ & $274.97 \mathrm{a}$ & 138.19a & $21.93 \mathrm{a}$ & $70.56 \mathrm{a}$ \\
\hline $\mathrm{CA} \times \mathrm{NZ}$ & $2111.20 \mathrm{a}$ & $1172.24 \mathrm{a}$ & $55.52 a$ & $178.50 \mathrm{a}$ & $273.00 \mathrm{a}$ & $150.71 \mathrm{a}$ & $21.73 \mathrm{a}$ & $70.56 a$ \\
\hline SEM & 130.38 & \pm 86.92 & \pm 1.96 & \pm 31.02 & \pm 28.01 & \pm 19.81 & \pm 1.48 & \pm 2.55 \\
\hline $\mathrm{P}>\mathrm{F}$ & $0.0028^{* *}$ & $0.0312^{*}$ & 0.7900 & 0.7911 & 0.9859 & 0.7323 & 0.9073 & 0.9816 \\
\hline \multicolumn{9}{|l|}{ By sex } \\
\hline Males & $2029.16 a$ & $1120.60 \mathrm{a}$ & $52.20 \mathrm{a}$ & $175.94 a$ & $277.14 a$ & $144.44 a$ & $21.92 \mathrm{a}$ & $70.34 a$ \\
\hline Females & $1994.05 \mathrm{a}$ & $1107.90 \mathrm{a}$ & $55.53 a$ & $175.04 \mathrm{a}$ & $269.58 \mathrm{a}$ & $142.17 \mathrm{a}$ & $21.77 \mathrm{a}$ & $70.74 \mathrm{a}$ \\
\hline SEM & \pm 155.17 & \pm 103.43 & \pm 2.33 & \pm 36.91 & \pm 33.33 & \pm 23.57 & \pm 1.76 & \pm 3.03 \\
\hline$P>F$ & 0.1246 & 0.3798 & 0.2561 & 0.8477 & 0.0959 & 0.3962 & 0.4293 & 0.2164 \\
\hline
\end{tabular}

a,b. Means within columns with different literals are different $\left(\mathrm{P}<0.05^{*}\right)$. 
In carcass yield, a general average of 55.38\% was obtained for all the crosses, higher than the 52\% reported by Boicoc (2002) in the progeny of NZ males with CA female crosses.

Regarding carcass parts, the loin and legs are the most economically important, representing $40 \%$ of the carcass, of which $16 \%$ is the loin and $24 \%$ the legs. There were no differences $(\mathrm{P}>0.05)$ between parental breeds.

\section{CONCLUSIONS}

The crosses between NZ parental breed rabbits showed better reproductive performance and viability in litter size at birth and weaning. Offspring from CA parents reported higher birth weights than the offspring from NZ parents. The results on the productive behavior of the $\mathrm{CA} \times \mathrm{NZ}$ cross progeny indicate that they are better when CA is used as the parental breed, with higher weekly weight gain and better feed conversion.

\section{ACKNOWLEDGMENTS AND/OR FINANCIAL SOURCE}

The authors wish to thank the Consejo Nacional de Ciencia y Tecnología (CONACYT) and the Livestock Program of the Colegio de Postgraduados with the research line "Technological Innovation and Food Security in Livestock" for the provided facilities to carry out this experimental study.

\section{REFERENCES}

Alpizar, J. (2007). Alimentos para conejos. Aspectos básicos de alimentación para la producción intensiva. Departamento de Nutrición Animal. Corporación PIPASA. Consultado el 25 de agosto 2020 http://www.engormix.com/ alimentosconejosaspectosbasicosarticulos949CUN.htm.

Barrón, M. del C., Herrera, J. G., Suárez, M. E., Zamora, M. M., y Lemus, C. (2004). Evaluación de características de canal en tres razas de conejos. Revista Cubana de Ciencia Agrícola, 38(1), 19-24.

Blasco, A., Ouhayoun, J. and Masoero, G. (1992). Study of rabbit meat and carcass. Criteria and terminology. http://world-rabbitscience.com/WRSA-Proceedings/Congress-1992-Corvallis/Communications-pdf/F01-BLASCO.pdf

Blumetto, O. (2007). Guía para el manejo de líneas genéticas de alto potencial en conejos para carne. Ed. Hemisferio Sur. 124p.

Boicoc, L. (2002). Comportamiento de algunos indicadores productivos y reproductivos de tres razas cunícolas. Centro Multiplicador cunícola de la granja. Consultado el 28 de agosto 2020 http://www.monografias.com/trabajos22/conejo/ conejo.shtml.

Brun, J. and Baselga, M. (2005). Analysis of reproductive performances during the formation of a rabbit synthetic strain. World Rabbit Sci.13:237-250. Doi: 10.4995/wrs.2005.514

Falconer, D. and Mackay, T. (1996). Introduction to quantitative genetics. 4th Edition, Prentice Hall, Longman Group Limited. $469 \mathrm{p}$.

Gallego, F. (2016). Conejos Nueva Zelanda y California sobre caracteres de la camada al destete. Rev. U.D.C.A Act. \& Div. Cient, 19(1), 115-121.

Khalil, M. and Al-Homidan, A. (2014). Genetic evaluation for growth traits and thermo tolerance parameters in synthesizing program of new rabbits. 2nd International Conference on Biotechnology Applications in Agriculture, Benha University, Moshtohor and Hurghada, 8- 11 April 2014, Egypt, 1-9.

Lleonart, F. (2001). Clasificación de las razas cunícolas. Curso de perfeccionamientos de la cunicultura industrial. España. pp. 
Lukefahr, S. and Cheeke, P. (1991). Rabbit project planning strategies for developing countries, 1: practical considerations. Livestock. Research for Rural Development (1): 2-9. Doi:org/10.4995/wrs.1991.470

Lukefahr, S., Nkwocha, H., Njakoh, H., Tawah, E., Akob, J., kongyu, F., Njwe, R. and Gudahl, D. (2000). Present status of the Heifer Project International - Cameroon Rabbit Programme: Back to the future. World Rabbit Sci. 8:75-83. Doi:org/10.4995/ wrs. 2000.440

Norma Oficial Mexicana NOM-033-SAG/ZOO-2014, Métodos para dar muerte a los animales domésticos y silvestres. Consultado el 27 de julio 2020 https://www.dof.gob.mx/nota_detalle.php?codigo=5405210\&fecha=26/08/20

Ortiz, H.; Rubio, L. (2001). Effect of breed and sex on rabbit carcass yield and metaquality. World Rabbit Sci. 9:51. Doi: 10.4995/ wrs.2001.445

Palmieri, D. (2006). Cría de conejos. Argentina, Consultado el 20 agosto 2020. http://www.engormix.com/s_articles_view.asp AREA $=$ CUN\&art $=29$

Piles, M.; Rafel, O.; Ramon, J.; Varona, L. (2005). Genetic parameters of fertility in two lines of rabbits with different reproductive potential. J. Anim. Sci. 83:340-343. Doi: 10.2527/2005.832340x

Piles, M.; Rafel, O.; Ramon, J.; Gómez, E. (2004). Crossbreeding parameters of some productive traits in meat rabbits. World Rabbit Science, 12: 139-148. Doi: 10.4995/wrs.2004.575

Ponce de León, R.; Guzmán, G.; Quesada, M. (2002). Crecimiento y eficiencia alimentaria de cuatro razas de conejos. Rev. Cubana Cienc. Agr. 36(1):7-14.

Ruales, F.; Manrique, C.; Cerón, M. (2007). Fundamentos en mejora genética animal. Ed. Medellín Colombia: L. Vieco e hijas Editores. 208p.

Trocino, A.; Xiccato, G.; Queaque, P; \& Sartori, A. (2003). Effect of transport duration and gender on rabbit carcass and meat quality. World Rabbit, Sci. 11:23. https://doi: 10.4995/wrs.2003.494

Vásquez, R.; Martínez, R.; Manrique, C.; Rodríguez, Y. (2007). Evaluación genética del comportamiento productivo y reproductivo en núcleos de Conejos de las razas Nueva Zelanda y Chinchilla. Ciencia \& Tecnología Agropecuaria, 8(1), 69-74. https:// doi.org/10.21930/rcta.

Youssef, Y. (2004). Heritabilities and common litter effects estimated by an animal model for pot-weaning growth traits in New Zealand White and Baladi Red rabbits. Egyptian Poultry Science, 24:205-21.

Zaghloul, A.; Khalil, M.; Iraqi, M.; Ramadan, Sh.; EL Nagar, A. (2019). Crossbreeding effects and polymorphic associations of genotypes of the gene with growth traits in rabbits a. Egyptian Journal, 2(29), 149-169. 